\title{
MULTICULTURALISM IN INDONESIAN NOVELS AS A CULTURE-UNITING DEVICE
}

\author{
Dr. Suroso \\ Yogyakarta State University \\ surosolsip@yahoo.com
}

DOI:10.5901/mjss.2014.v5n22p130

\begin{abstract}
This study aims to describe multiculturalism in Indonesian novels in the post-independence era. The sources are eight novels written from 1970s to 1990s. Multiculturalism is analyzed using social theories on the basis of cultural pluralistic mosaic. The findings show that multiculturalism in Indonesian novels is manifested in the use of a variety of languages in the works, understanding of social classes, citizens' devotion, inter-religion understanding, expressions of affection, and inter-nation marriages. Multicultural novels can serve as a culture-uniting device.
\end{abstract}

Keywords: multiculturalism, pluralism, culture-uniting device

\section{Introduction}

Indonesia has more than 13, 000 islands and the people speak in more than 500 languages, have a variety of beliefs and religions, and consist of several ethnic groups, resulting in the difficulty appreciating multicultural facts. Frictions appear among people with different beliefs and religions due to radicalism and a show-off of ethnic characteristics resulting from the regional autonomy policy necessitating that a leader must be an indigenous person and the existence of envy of particular ethnic groups because of economic inequality. All of these affect multiculturalism in Indonesia.

Besides, the understanding of multiculturalism may vary because of the infiltration of foreign cultures in their variety of forms such as fashion and lifestyle, the economic and cultural penetration, the information access, and the communication and transportation, making multicultural adaptation easy. The cultural penetration due to globalism is unavoidable in society. As a result, local values have to compete with global values parallel to advancement in education, science, and technology, resulting in penetration that can explain the relationship of individuals in society with a variety of religions, ethnic groups, languages, and cultures.

Indonesian novels that reflect multiculturalism can be used as one of the media for understanding multiculturalism because novels contain ideas, views, and enlightenment for issues related to ethnic relationship, religions, social classes, and communities with a variety of problems. Understanding and appreciation of multiculturalism will eventually be able to create understanding of cultural differences, which are unavoidable.

Through characters, settings, atmospheres, and issues presented in novels with a variety of ethnic groups and cultures in Indonesia, people can use them to contribute to strengthening a culture-uniting device to avoid conflicts related to religions, ethnic groups, and social classes in order to appreciate multiculturalism.

A novel as a literary work genre presents a variety of problems in human life, including relationship among human beings, interaction between human beings and their environments, interaction between a human being and the self, and interaction between a human being and God. A novel as a literary work contains the author's dialogs about life and environment. It is an imaginative work based on the author's consciousness to offer life model that s/he idealizes in dealing with problems in society and to express multicultural discourses.

The novels discussed in this paper are those related to multiculturalism in terms of issues related to religions, ethnic groups, and social classes and those written during the post-independence era in a variety of contexts. They are already criticized by literary critics and have a lot of readers. Therefore, such novels are assumed to influence the readers, moving in a parallel way to Indonesian multicultural society. 
The novels under discussion are Bekisar Merah (2005) and Kubah (2011) by Ahmad Tohari, Burung-burung Manyar (1993) by Y. B. Mangunwijaya, Keluarga Permana (1978) by Ramadhan Karta Miharja, Laskar Pelangi (2006) by Andrea Hirata, Para Priyayi (2003) by Umar Kayam, Pengakuan Pariyem (2008) by Linus Suryadi AG, Canting (2007) by Arswendo Atmowiloto, and Tarian Bumi (2003) by Oka Rusmini.

\section{Multicultural Politics in Several Eras}

Indonesia has diversity in terms of ethnic groups, religions, races, social classes, customs, and traditions. Such a reality is attributable to the geographical factor; there are thousands of islands and people live in separate islands. In Indonesia there are different levels in terms of culture and civilization; among communities, there are wide cultural disparities or gaps. Most people still live in the agricultural world with their local cultures and few people have entered the world of information and technology with global culture (Azra, 2007).

With such geographical and cultural conditions, since the independence the Indonesian government has formulated a cultural political strategy to accommodate a variety of existing cultures in accordance with Constitution 1945 Article 34 regarding attempts to develop culture. Indonesia's cultural strategy was influenced by the Dutch and Japanese colonialism during the colonial periods and this continued in the old order era during the administration of President Soekarno as the first president of Indonesia (1945-1966), in the new order era during the administration of President Soeharto as the second president who was an army general (1966-1998), and in the reform order during the administration of President BJ Habibie as the third president who was a doctor of airplanes.

During the colonial period, the Dutch applied the ethical policy to compensate colonialism in the fields of irrigation, immigration, and education. The traces of the Dutch ethical policy are still left today. The agricultural system in Indonesia still adopts the irrigation system made by the colonial government in the form of river dams and irrigation channels. In addition, there are still architectural traces in buildings which were formerly Dutch buildings in several big cities in Indonesia. The distribution of people to several islands during the Dutch occupation was made to fulfill the needs for workers in the agricultural sector to process agricultural crops such as tobacco, clove, nutmeg, pepper, quinine, and other agricultural commodities. Besides, the distribution of people was also made to satisfy the needs for workers in lead, oil, gold, and other mineral mining.

The traces of the Dutch ethical policy in education were apparent in the establishment of schools with the Western style for indigenous people who were employed as lower-class employees for the benefit of the Dutch colonial government. Meanwhile, for higher education for the Dutch people or indigenous aristocrats, STOVIA was established. Through such higher education, national movement figures came up. However, the Dutch colonial government still applied social classes for citizenship. The Dutch divided Indonesian people into groups of White Skin (European and Indo-European people), Foreign East (Chinese, Arabic, and Indian people), and Indigenous (native inhabitants). The differentiation of citizens had implications in relation to laws and treatments. The White Skin and Foreign East people conformed to the Dutch laws and the Indigenous people conformed to the custom laws. As a result, the former was able to obtain the Dutch higher education and the latter was able to obtain only lower education.

During the Japanese colonial era, there was an opposition against the hegemony of western values and cultures. However, at that time there were reforms among young intellectuals pioneered by Sutan Takdir Alisyahbana. They invited literary authors to come back to eastern values. The eastern values, however, were not those existing in kingdoms of Sriwijaya, Majapahit, and Mataram, but those in the Indonesian culture free of the pre-Indonesian cultures and oriented to the western culture. The westernization of the pre-Indonesian cultures got an opposition. Those who were against the western culture were of the opinion that they could select what was good in both values to develop the Indonesian culture. The Japanese colonialism which lasted only 3.5 years did not have much effect on the color of the Indonesian culture. During this era, there were physical destructions resulting from the romusha (forced labor) and forced cultivation policies.

During President Soekarno's administration, the government formulated the national identity in Pancasila (five principles) and Constitution 1945. The government also embraced all groups in NASAKOM (Nasionalisme, Agama, dan Komunis = Nationalism, Religion, and Communism). The birth of NASAKOM was a manifestation of Soekarno's appreciation of pluralism. During this era, nationalist parties such as PNI (Partai Nasional Indonesia = Indonesian National Party) and religion-based parties such as PSII (Partai Syarikat Islam Indonesia = Indonesian Islamic Union Party), NU (Nahdatul Ulama = Muslim Clergy Awakening Party), Indonesian Christian Party, Indonesian Catholic Party, and PKI (Partai Komunis Indonesia = Indonesian Communist Party) flourished. However, Soekarno's closeness to PKI and the enforcement of the Guided Democracy through the Decree of 5 July 1959 gave authority to LEKRA (Lembaga Kebudayaan Rakyat = People's 
Cultural Institution), an organization under Indonesian Communist Party, which triggered a cultural polemic between LEKRA and MANIKEBU (Manifes Kebudayaan = Cultural Manifestation), coloring the course of Indonesian literature.

The birth of LEKRA was opposed by young intellectuals lead by Goenawan Mohamad with MANIKEBU refusing the statement of politics as commander social realism. MANIKEBU proposed a concept underlying arts on the basis of universal humanism in viewing the national culture. The conflict between LEKRA and MANIKEBU indicated that in that era proponents of each group appreciated differences.

During President Soeharto's administration, the government tried to deal with pluralism issues in the jargon Bhinneka Tunggal Ika (Unity in Diversity) although it remained a jargon. The government enforced cultural uniformity politics in order to maintain power. The government's jargon accommodated plurality but in reality the cultural practices were mono-cultural, dictatorial, and authoritarian. If a thing threatened the power maintenance, the government was ready to carry out repressive and discriminative actions and even violence was legally conducted by the government. The most outstanding action was that done to ex-prisoners of G30S/PKI. The mono-cultural politics on behalf of development stability destroyed the local genius culture. All organizations had to use the single foundation, namely Pancasila.

During BJ Habibie's administration, known as the reform era, the government annulled Pancasila as the single foundation in introduced other ideologies, especially religion-based ideologies. The government also introduced decentralization or local autonomy. During this era, the press freedom developed, marked by the issuance of Act Number 40 Year 1999 regarding press that gave freedom to the press industry management not under the government's control like what happened during Soeharto's regime. The traces of freedom in the government at that time were left in multicultural practices, especially in the freedom of expressing opinions, embracing religions, and being involved in politics. Literary people nowadays can express ideas on political, social, and cultural matters without the government's censorship. A political survey which was prohibited during Souharto's administration could be freely conducted during BJ Habibie's administration.

\section{Multiculturalism in Indonesian Novels}

Multiculturalism is related to groups of people with different cultures and characteristics living and residing in a particular place and they can be differentiated from one group to another. Each society has its own culture and it becomes the society's characteristic. Multiculturalism is related to the idea and attitude to view cultural diversity as a fundamental reality in society's life. A person's open attitude towards shared life will accept plurality as a must which is unavoidable.

According to a social theory proposed by Gracia (1982), there are three types of multiculturalism. The first is the Anglo Conformity, in which individuals with different backgrounds in terms of religions, ethnic groups, and cultures are united in a dominant union. The second is the Ethnic Synthesis, in which individuals with different backgrounds are united in a new identity union, and former religions, ethnic groups, languages, and cultures mix and become a new identity. The third is the Cultural Pluralism Mosaic Analogy, in which individuals with different backgrounds in terms of religions, ethnic groups, and cultures have rights to express their cultural identities democratically without marginalizing the minority group's cultural identity. For example, when individuals in society have Javanese cultural background, national background, or international background, they have rights to express their cultural identities and to develop their cultures without disturbing each other. These three are able to develop pluralistic society.

Indonesian novels reflecting multiculturalism can be used as of the media to improve understanding multiculturalism because novels contain ideas, views, and enlightenment for issues concerning relationships among ethnic groups, religions, social classes, and communities with a variety of problems. Understanding and appreciation of multiculturalism through novels will eventually be capable of creating understanding of cultural differences which are unavoidable. Understanding of multicultural novels will in the end strengthen the cultural bond among cultures, including national and international cultures. Therefore, there is no dichotomy anymore concerning the national culture and the local culture, and even every individual or community is a culture creator (Dewanto, 1992).

\section{Multicultural Novels as a Culture-Uniting Device}

Understanding of multicultural literature cannot be separated from the idea of contextual literature and postmodernism. Contextual literature develops new realistic ideas by placing literature as a factual historical product to understand real problems in society (Heryanto, 1985). Such a historical process, as Faruk HT (2001) states, is a struggle of political interests among society members. Therefore, the center of the literary world totality is political interests. Historical novels by Pramudya Ananta Tur, YB Mangunwijaya, and Mochtar Lubis show these.

In addition to representing political perspectives, literature presents a cultural political perspective in deconstructing the mainstream of the patriarchal view. Saman (1998), a novel by Ayu Utami, and Tarian Bumi (2000) by Oka Rusmini provide 
answers that literature is capable of positioning problems of women's bodies which have so far been exploited by men. Saman, besides exploring women's rights of their own bodies, also explores conflicts of economic interests between local society and national, or even global, society. In Tarian Bumi, women are able to set their own goal although they have to oppose the strict division regarding social stratification on the basis of castes in Balinese cultures.

Multicultural issues are also presented in YB Mangunwijaya's novels Burung-burung Manyar (1981), Roro Mendut (1983), and Burung-burung Rantau (1993), Linus Suryadi AG's Pengakuan Pariyem (2008), and Umar Kayam's Para Priyayi (2003). The atmospheres in these novels stimulate pluralism in Bahasa Indonesia (Indonesian language) because the characters use the Indonesian, Javanese, English, and Dutch languages. The characters in these novels also refer to social classes in Javanese society with their affection, humility, sincerity, and wholeheartedness as shown by the following quotations:

"Sedang Kang Lantip, dialah guru saya. Bukan dia banyak mengajari saya, tapi karena kerendahan hatinya, ketulusan dan keikhlasan hatinya. Sejak semula saya mengenalnya di Wanagalih dan Wanalawas saya sudah langsung menyayanginya. Kemelaratan dan kemiskinan asal usulnya sebagai anak pungut di Setenan Wanagalih, tidak pernah membuatnya kecil hati, terlalu rendah diri, minder. Sifatnya yang prasaja, sederhana, apa adanya dan biasa itu sering membuat saya panik di dalam hati" (Kayam, 1992: 283).

("Meanwhile, Kang Lantip is my teacher, not because he teaches me much, but because of his humility, sincerity, and wholeheartedness. Since I knew him for the first time in Wanagalih and Wanalawas, I directly had affection for him. The poverty due to his origin and position as an adopted child in Setenan Wanagalih has never made him annoyed and inferior. His plainness, modesty, and being realistic and ordinary often make me in a panic heartily.")

The quotation shows a humble attitude making Hari have affection for Lantip although Lantip is not his own elder brother. Lantip, who was born in a poor family, respects people who help him so that he can survive.

Issues of the relationship between aristocrats and common people and masters and servants are presented in the novel Pengakuan Pariyem (2008). When it is revealed that RM Cokro Sentono's son, Raden Bagus Ario Atmojo, makes the servant, Maria Magdalena Pariyem, pregnant, he is willing to take care of the baby in her womb without embarrassment. The principles of harmony, mutual help, affection, and joy which become part of multiculturalism are narrated in the novel, which has been translated into English and Dutch. In a similar manner, a harmonious social relationship is depicted in Canting (2007), a novel by Arswendo Atmowiloto. The novel presents the smartness of a woman to survive as a business woman. Through her business she can support 112 batik employee families, although she was formerly a servant before getting married to Raden Ngabehi Setrokusumo. The novel shows that women can be autonomous in running businesses in society (Wiyatmi, 2012: 228).

Issues of devotion, social relationship, affection, and perseverance in carrying out professional demands are depicted in the novel Laskar Pelangi (2006). The novel has been translated into German and English, the title of the English edition being Rainbow Troops. It tells about ten elementary school children in Belitong struggling for obtaining primary education. The exemplar deeds in the novel are the devotions of Bapak Harfan and Ibu Muslimah, who teach in a remote area with poor educational infrastructure facilities. However, as teachers they are capable of educating elementary school children to develop noble characters that respect others without looking at ethnic, social, and economic backgrounds. The novel becomes a bestseller in Indonesia and is filmed with the same title. One of the effects is that the setting of the novel becomes a tourist destination.

An inter-religion marriage issue is presented in Keluarga Permana (1978), a novel by Ramadhan Karta Hadimaja. It presents a perspective concerning consequences of a marriage with different religious backgrounds. It is about a Moslem family that educates their daughter strictly without giving her chances for socialization. Permana, after his resignation, builds a boarding house. FX Soemarto, a young man who is a Catholic, is a tenant who falls in love with the girl, Farida, who has so far been confined in isolation. Then, Farida is pregnant, making all family members who are Moslems angry. After getting married and converting into a Catholic, Farida finally dies when she is hospitalized. Before she dies, the nurse treating her whispers syahadat (Moslem confession of faith) and she dies as a Moslem. From the novel it can be learned that to manage a family well it is necessary to respect women and one's religion or belief in order to live happily. The understanding of the author, who is a Moslem, and its readers leads to inter-religion faith understanding.

Forgiveness in the Islamic perspective is presented in Kubah (2011), a novel by Ahmad Tohari. Karman, as a Moslem, converts himself into a communist and an atheist because he is provoked by revenge. However, because of Haji Bakir's exemplary deeds, affection, attention, and forgiveness, eventually Karman realizes his mistakes in embracing communist 
ideology and becomes a Moslem again and has an opportunity of making a mosque dome without payment. Karman tries to find his way back to God.

Issues of inter-nation marriage are depicted in the novels Saman (1998) by Ayu Utami, Burung-burung Manyar (1981) by YB Mangunwijaya, and Bekisar Merah (1997) by Ahmad Tohari. The character Mbok Wiraji, who is raped by a Japanese soldier, gives birth to a baby daughter called Lasiah or Lasi, who is very beautiful as an Indo-Japanese girl. However, because she is from a lower social class, Lasi cannot have an option on the basis of her conscience, although actually she can have it.

Understanding of issues of social, political, religious, and ethnic interactions in multicultural novels will eventually be capable of providing strong insights into multiculturalism as a culture-uniting device. Understanding and appreciation of differences in the end will strengthen pluralistic principles which are unavoidable in Indonesia with its slogan Unity in Diversity leading to true multicultural society.

\section{Closing Remarks}

To end the discussion, it can be concluded that multicultural novels can play a role as a culture-uniting device in global society which tends to be pluralistic and multicultural. However, the multicultural nature does not mean value-free. Multicultural novels containing local, national, and global cultures can express cultural identities without neglecting unique characteristics through the principle of appreciating new cultures.

Multicultural novels that can be used as a culture-uniting device are those the authors write as media of communication among nations to present multicultural values without confinement of identities, ethnic groups, religions, and social classes. Multicultural novels can serve as an alternative for expressing multiculturalism in modern society.

In the midst of the nation's low interest in reading and the increasing inclusive spirit, multicultural novels are necessary as a reading alternative providing enlightenment at school and higher education. The socialization of multicultural values can be done in literature learning at school, multicultural novel discussions, and seminars on multicultural values carried out in both academic forums and co-curricular activities.

\section{References}

Daftar Pustaka

Atmowiloto, Arswendo (2007) Canting. Jakarta: Gramedia Pustaka Utama. Cet. 3

Azra, Azyumardi (207) "Keragaman Indonesia: Pancasila dan Multikulturalisme" dalam Keragaman Suku Agama, Ras, Gender, sebagai Modal Sosial untuk Demokrasi dan Masyar Kat Madani: Tantangan dan Peluang: Yogyakarta: Fakultas psikologi UGM

Dewanto, Nirwan (2002)"Masih Perlukah Sejarah Sasta" Esai-Esai Bentara. Jakarta: Penerbit Buku Kompas.S,

Dewanto, Nirwan (1992) "Seni di Zaman Global" Festifal mahasiswa Senise se-Indonesia 1992. Yogyakarta: Senat Mahasiswa ISI Yogyakarta

Faruk, HT (2001) Beyond Imagination Sastra Muthakir danldeologi. Yogyakarta: Gama Media.

Garcia, Ricardo L. 1982. Teaching in Pluralistic Society: Concepts, Models, Strategies. New York: Harper \& Row Publisher. Hirata, Andrea (2006). Laskar Pelangi. Yogyakarta: Bentang.

Heryanto, Ariel (1985) Perdebaan Sastra Kontekstual. Jakarta: Rajawali Press.

Imron, Ali al Ma'ruf (2011) "Peran Sastra Multikultural Sebagai Media Antarbangsa" dalam Literasi Jurnal IImu-IImu Humaniora. Vol 1 Nomor 1. Jember: Universita Negeri jember.

Karta Hadimadja, Ramadhan (1978) Keluarga Permana. Jakarta: Pustaka Jaya

Kayam, (2003) Para Priyayi. Jakarta: Pustaka Utama Grafiti

Mangunwijaya, YB (1993) Burung Burung Manyar. Jakarta: Jambatan

Rusmini, Oka (2003) Tarian Bumi. Magelang : Indonesia Tera.

Salam, Aprinus (2009) Politik Multikulturalisme Novel-Novel Indonesia. Yogyakarta: Program Studi Sastra Fakultas IImu Budaya. Universitas Gadjah Mada.

Suryadi Ag, Linus (2008.) Pengakuan Pariyem. Yogyakarta : Pustaka Pelajar. Cet. 7

Sekretariat Negara (1999) Undang - Undang No 40 Tahun 1999 Tentang Pers. Jakarta: Setneg

Tohari, Ahmad (1997) Bekisar Merah. Jakarta Gramedia

Tohari, Ahmad (2011) Kubah. Jakarta: Gramedia 
Wiyatmi (2012) Kritik Sastra Feminis. Yogyakarta: Ombak Tohari, Ahmad (1997) Bekisar Merah. Jakarta Gramedia Tohari, Ahmad (2011) Kubah. Jakarta: Gramediar

${ }^{*}$ Dr. Suroso, M.Pd., M.Th. Lecturer at Departmen Language and Art Education, Faculty Language and Art, Yogyakarta State University, Indonesia. 